International Research Journal of Management, IT \& Social Sciences
Available online at https://sloap.org/journals/index.php/irjmis/
Vol. 7 No. 1, January 2020, pages: 177-184
ISSN: 2395-7492
https://doi.org/10.21744/irjmis.v7n1.835

\title{
Effect of Leverage, Free Cash Flow, Corporate Governance, Growth and Risk Management on Earnings Quality
}

Gede Sedana Wibawa Yasa ${ }^{a}$ Made Gede Wirakusuma ${ }^{b}$ I Gusti Ngurah Agung Suaryana ${ }^{c}$

\section{Article history:}

Submitted: 27 November 2019

Revised: 09 December 2019

Accepted: 12 January 2020

\section{Keywords:}

corporate governance; earnings quality;

free cash flow;

growth;

leverage;

risk management;

\section{Corresponding author:}

Gede Sedana Wibawa Yasa,

Udayana University, Denpasar, Indonesia.

Email address: sedanawibawa@yahoo.com

\begin{abstract}
This study aims to obtain empirical evidence about the effect of leverage, free cash flow, corporate governance, growth, and risk management on earnings quality. The study population is the banking sector companies listed on Indonesia Stock Exchange from 2016 to 2018. Data were collected using the purposive sampling method. 41 companies were obtained as research samples to be analyzed using multiple linear regression analysis techniques. The test results showed the variable leverage, managerial ownership and risk management have a negative and significant effect on earnings quality. It was also indicated the variable free cash flow and growth have a positive and significant effect on earnings quality.
\end{abstract}

International research journal of management, IT and social sciences (C) 2020. This is an open access article under the CC BY-NC-ND license (https://creativecommons.org/licenses/by-nc-nd/4.0/).

\footnotetext{
${ }^{a}$ Udayana University, Denpasar, Indonesia

${ }^{\mathrm{b}}$ Udayana University, Denpasar, Indonesia

${ }^{c}$ Udayana University, Denpasar, Indonesia
} 


\section{Introduction}

Financial statements are records of company financial information in an accounting period. It is used to describe the company's performance. The Indonesian Accountants Institute (2015) defined the financial statements as a presentation of the position structure and financial performance of an entity. Decision making and financial statements are also a tool to convey the company's financial performance and management responsibility for its performance. The existence of management actions reports earnings is not in accordance with the actual conditions. The company will result in earnings being doubted (Wati \& Putra, 2017).

Financial statements have become one of the central issues as a source of information misuse can harm the parties concerned as users. To present, there have been many financial scandals on companies by manipulating the published financial statements. In Indonesia, there are several company cases indicated to manipulate their financial statements. For example, is the case of PT. Bank Bukopin.Tbk in 2018. The bank was proven to have revised its financial statements in 2016, the revision appeared on April 25, 2018, with significant changes in a number of variables in the financial statements, for example, profit in 2016 was originally recorded at IDR. 1.08 trillion but in 2017 financial statements the company's profit was recorded at IDR. 183.53 billion (Dwiantika, 2018). The actions taken by managers as in this phenomenon are the result of a number of internal and external factors affect the manager's company to manipulate financial statements using accrual policies. Previous research on the factors influence earnings quality has been done, but the results are still experiencing inconsistencies. Therefore, this research was conducted by selecting earnings quality as the objective research and using several variables, namely leverage, free cash flow, corporate governance, growth and risk management as variables can affect company earnings quality.

Leverage and free cash flow within a company are agency conflict sources between managers and shareholders. Conflicts of interest between principals and agents can be minimized through a monitoring mechanism, namely good corporate governance, the main purpose is to regulate, control and aligning various interests within the company (Dira \& Astika, 2014). Siallagan \& Machfoedz (2006), stated managerial ownership structure is a very important factor. It is closely related to the control of the company's operational activities. The lack of share ownership by managers is considered to cause the resulting earnings to be less quality. Jensen \& Meckling (1976), suggested the interests of managers and shareholders can be harmonized if the manager has a larger percentage of the company's shares. This indicates managerial ownership can reduce the desire to manipulate actions. It will improve the quality of reported earnings. With the creation of good corporate governance, the confidence of investors and creditors will increase. This will directly have an impact on the growth company opportunity, the opportunity to growth explains the company's future growth prospects. According to Fidyati (2003), Growth is a company growth compared to the previous period.

Companies with large growth opportunities will provide high profitability in the future. They will produce more persistent profits. High growth rates must be accompanied by good risk management. It is part of the overall business strategy. It is intended to contribute to protecting and increasing shareholder value (Hoyt \& Liebenberg, 2011). The application of good risk management will have a positive impact on company performance which will indirectly affect the quality of the generated profits. Based on previous research conducted by Marpaung (2019); Agustia (2013); and Wulansari (2013), showed the leverage variable has a negative and significant effect on earnings quality. This shows companies have high leverage ratios mean a higher proportion of debt compared to assets proportion. It will tend to manipulate in the form of earnings management which will affect the decrease in the quality of the company's earnings. H1: Leverage has a negative effect on earnings quality

Free cash flow within a company will affect the actions taken by managers and shareholders. It shows an illustration for investors dividends distributed by the company is not just strategies to get around the market with the intention of increasing the company value. This statement is supported by previous research conducted by Zakaria \& Daud (2013); Kodriyah \& Fitri (2017), found free cash flow has a positive effect on earnings quality. Wherein the higher free cash flow available in a company, the healthier company has cash available for growth, debt service and dividends.

H2: Free cash flow has a positive effect on earnings quality

Agency theory explained information asymmetry occurs within the company is caused differences in the information received by managers and shareholders resulting in conflict. However, increasing the manager's share ownership can be avoided due to managers will take on the role of managers who manage as well as company owners. Previous research conducted by Wahyuni (2010), as well as Putra et al. (2017), found managerial shareholding succeeded in becoming a mechanism could reduce agency problems in the company, conclusions from the results of their research 
stated the higher share ownership management, the more quality profit generated the company, this is because the manager arranged company also acts as the owner of the company.

H3: Managerial ownership has a positive effect on earnings quality

Company with a high growth percentage will have poor earnings quality because they are allegedly conducting accrual policies in the form of earnings management. This statement is supported by previous research conducted by Tong \& Miao (2011); Nwaeze (2010); Pitria (2017); and Ramanuningsih (2012), found growth has a negative effect on earnings quality. This shows the higher the growth company rate, it is allegedly going to do earnings management to attract investors to invest in the company.

H4: Growth has a negative effect on earnings quality

Risk management is part of the overall business strategy and is intended to contribute to protecting and increasing shareholder value (Hoyt \& Liebenberg, 2011). The high-level management risk within a company will produce good earnings quality. This statement is supported by the results of previous research conducted by Nasih (2014); Dewi \& Dewi (2017); Fahmi (2013); and Wulansari (2013), showed that risk management is proxied by ratio liquidity has a positive and significant effect on earnings quality. The result showed companies with a good level management risk will be able to suppress the opportunist attitude of managers in using their accrual policies.

H5: Risk management has a positive effect on earnings quality

\section{Materials and Methods}

The study population is the banking sector companies listed on Indonesia Stock Exchange from 2016 to 2018 . The sampling technique used a purposive sampling method to get 41 companies as research samples. The data analysis technique used multiple linear regression:

$\mathrm{Y}=\alpha+\beta 1 \mathrm{X} 1+\beta 2 \mathrm{X} 2+\beta 3 \mathrm{X} 3+\beta 4 \mathrm{X} 4+\beta 5 \mathrm{X} 5+\varepsilon$.

Information:

$\mathrm{Y}=$ earnings quality

$\alpha=$ constant number

$\beta=$ regression coefficient

$\mathrm{X} 1$ = leverage

$\mathrm{X} 2$ = free cash flow

$\mathrm{X} 3$ = managerial ownership

$\mathrm{X} 4$ = growth

$\mathrm{X} 5$ = risk management

$\varepsilon \quad=$ other factors that affect the dependent variable $(\mathrm{Y})$

\section{Results and Discussions}

Based on the results of multiple linear regression analysis was processed using SPSS 21.0 for Windows with the obtained results in Table 1.

Table 1

Regression test results

\begin{tabular}{|c|c|c|c|c|c|}
\hline \multirow[t]{2}{*}{ Variable } & \multicolumn{2}{|c|}{ Unstandardized Coefficients } & \multicolumn{2}{|c|}{$\begin{array}{l}\text { Standardized } \\
\text { Coefficients }\end{array}$} & \multirow[b]{2}{*}{ Sig. } \\
\hline & $\mathrm{B}$ & Std. Error & Beta & $\mathrm{t}$ & \\
\hline (Constant) & $-0,095$ & 0,048 & & $-1,952$ & 0,053 \\
\hline $\mathrm{X} 1$ & 0,137 & 0,050 & 0,299 & 2,757 & 0,007 \\
\hline $\mathrm{X} 2$ & $-0,202$ & 0,080 & $-0,188$ & $-2,529$ & 0,013 \\
\hline
\end{tabular}

Yasa, G. S. W., Wirakusuma, M. G., \& Suaryana, I. G. N. A. (2020). Effect of leverage, free cash flow, corporate governance, growth and risk management on earnings quality. International Research Journal of Management, IT and Social Sciences, 7(1), 177-184. https://doi.org/10.21744/irjmis.v7n1.835 


\begin{tabular}{llllll}
\hline X3 & 0,179 & 0,078 & 0,169 & 2,290 & 0,024 \\
X4 & $-0,301$ & 0,040 & $-0,552$ & $-7,456$ & 0,000 \\
X5 & 0,015 & 0,007 & 0,242 & 2,237 & 0,027 \\
F Count & & 15,000 & & & 0,000 \\
Adjusted $R^{2}$ & & 0,365 & & & \\
\hline
\end{tabular}

Source: Processed data, 2019

Based on Table 1, the regression equation can be arranged as follows.

$\mathrm{Y}=-0,095+0,137 \mathrm{X} 1-0,202 \mathrm{X} 2+0,179 \mathrm{X} 3-0,301 \mathrm{X} 4+0,015 \mathrm{X} 5+\varepsilon$.

Based on the multiple linear regression model, it can be interpreted. The results of $F_{\text {count }}$ is 15,000 with a significance level is 0,000 which is smaller than the significance level is 0.05 . It can be concluded the regression model made is suitable for use in research. The results of the determination coefficient test with an adjusted R2 value of 0.365 this means $36.5 \%$ variation of earnings quality is influenced by variations in leverage (X1), free cash flow (X2), managerial ownership (X3), growth (X4) and risk management (X5) as the influencing variable. The remaining $63.5 \%$ is influenced by other factors outside the model.

\subsection{Effect of leverage on earnings quality}

The tested results on leverage variable on earnings quality show t-value 2.757 with t-significance 0.007 . It is smaller than the real level $(\alpha)$ used is 0.05 . These results indicate leverage has a positive effect on discretionary accruals as a proxy for earnings quality. This indicates leverage has a negative influence on earnings quality. It is caused by the difference in direction between discretionary accruals and earnings quality wherein the more positive the discretionary accruals value is the resulting earnings quality value will be increasingly negative and vice versa. Thus $\mathrm{H} 1$ which stated leverage has a negative effect on earnings quality is accepted.

This finding is consistent with the results of research conducted by Marpaung (2019); Dewi et al. (2019); Agustia (2013); and Wulansari (2013), wherein their research showed variable leverage has a negative and significant effect on earnings quality. The study result explained companies with high levels of leverage will have a high-risk level. Managers at companies have a high degree of leverage usually use accrual policies by making earnings management. Therefore, the company's performance looks good and can generate large profits. The main objective is to gain the trust of creditors in maintaining profitability to meet receivables agreements. If the leverage ratio in a company increases the potential for managers to arrange earnings higher, thus, the resulting earnings quality becomes low (Goyal, 2010).

\subsection{Effects of free cash flow on earnings quality}

The tested result on free cash flow variable on earnings quality show a t-value is -2.529 with a t-significance is 0.013 . It is smaller than the real level $(\alpha)$ used is 0.05 . These results indicate free cash flow has a negative effect on discretionary accruals as a proxy for earnings quality. Therefore, it can be concluded free cash flow has a positive effect on earnings quality. This is due to differences in direction between discretionary accruals and earnings quality which is increasingly positive the value of discretionary accruals. The value of the resulting earnings quality will be more negative and vice versa. Thus, $\mathrm{H} 2$ which stated free cash flow has a positive effect on earnings quality is accepted.

This finding is consistent with the research results presented by White et al. (2003); Zakaria \& Daud (2013); and Kodriyah \& Fitri (2017), the results stated free cash flow has a positive effect on earnings quality. It can be concluded the higher the free cash flow available in a company. The healthier company is because it has available cash for growth, debt payments, and dividends. In addition, the results of this study also explain companies with high levels of free cash flow tend to avoid the existence of earnings management practices. The aim is to maintain the credibility of the financial statements and earnings quality produced. Good earning quality will show how the company's ability to distribute dividends. Therefore, on the high free cash flow and without the company's earnings management can increase its share price because investors see the company has excess cash for dividend distribution. 


\subsection{Effect of managerial ownership on earnings quality}

The results of managerial ownership tested earnings quality shows t-value is 2.290 with t-significance is 0.024 . It is smaller than the real level $(\alpha)$ used is 0.05 . These results indicate managerial ownership has a positive effect on discretionary accruals as a proxy of earnings quality. It can be concluded managerial ownership has a negative effect on earnings quality. This is caused by differences in direction between discretionary accruals and earnings quality. Wherein the more positive the value of discretionary accruals, the value of the resulting earnings quality will be more negative and vice versa. Therefore, H3 which stated managerial ownership has a positive effect on earnings quality is rejected.

This finding is consistent with the results of previous studies conducted by Peasnell et al. (2005), stated the higher the percentage of managerial ownership, the more prone to manager's actions to conduct earnings management will cause the resulting earnings quality to be low. The negative influence of managerial ownership on earnings quality can be caused the regulations governing the percentage of share ownership on managerial. Wherein the tabulated data obtained on the average share ownership by managers in state-owned banks is only $2.5 \%$ and $4 \%$ in commercial banks. This study results indicate an increase in the percentage of managerial ownership is considered not able to overcome agency problems occur in the company. This is because the higher managerial ownership will result in managers more free to use the company's accrual policy, thus, the result of earnings quality becomes bad.

\subsection{Effect of growth on earnings quality}

The results of the growth variable test on the variable earnings quality show t-value is $-7,465$ with t-significance is 0,000 . It is smaller than the real level $(\alpha)$ used is 0.05 . These results indicate growth negatively affects discretionary accruals as a proxy of earnings quality. It can be concluded growth has a positive effect on earnings quality. This is caused by differences in direction between discretionary accruals and earnings quality wherein the more positive the value of discretionary accruals is the value of earnings quality will be more negative and vice versa. Thus, H4 which stated growth negatively affects earnings quality is rejected.

This finding is consistent with previous research conducted by Nazarpour \& Norouzi (2015). The results found there was a positive and significant relationship between growth variables and earnings quality. The positive effect of growth variables on earnings quality in banking companies can be caused an increase in the number of deposits, savings and current accounts. They can directly affect the total assets held for growth. Another factor can influence, it is the allowance for receivables losses, wherein the allowance for receivables will directly affect the total assets owned the bank because when the receivables reserves increase. The assets will decrease and vice versa. The results of this study indicate companies with high growth rates will avoid earnings management actions. This is conducted in an effort to maintain the quality of the generated profits. This step is done on management to maintain good performance has been obtained by the company, where the higher the opportunity to grow the company the higher the chance for companies to get or increase profits earned by the company in the coming period. Thus, good quality profits are generated (Collins \& Kothari, 1989).

\subsection{Effect of risk management on earnings quality}

The result of risk management variable testing on earnings quality shows t-value is 2.237 with t-significance is 0.027 . It is smaller than the real level $(\alpha)$ used is 0.05 . These results indicate risk management has a positive effect on discretionary accruals as a proxy for earnings quality. It can be concluded risk management has a negative effect on earnings quality. This is caused by differences in direction between discretionary accruals and earnings quality where the positive value of discretionary accruals, the value of earnings quality will be more negative and vice versa. Thus, H5 which stated risk management has a positive effect on earnings quality is rejected.

This finding is consistent with previous research conducted by Kamaludin et al. (2016). It is found high-risk management results in a decrease in earnings quality. This occurs because managers with conservative attitudes are motivated to manage earnings, on the aim of getting a balance between various types of company risk going forward. The negative influence of risk management as measured on the ratio of liquidity to earnings quality can be caused to bank policies use more long-term debt compared to short-term debt, wherein banks prefer to use long-term debt because the procedure to obtain long-term debt and must be held audits before debt can be given. Furthermore, managers tend to carry out accrual policies to ensure banks are in good condition and balance at the time of the CAMEL report (Capital, Asset, Management, Earnings, Liquidity) each year. Therefore, the results of this study indicate

Yasa, G. S. W., Wirakusuma, M. G., \& Suaryana, I. G. N. A. (2020). Effect of leverage, free cash flow, corporate governance, growth and risk management on earnings quality. International Research Journal of Management, IT and Social Sciences, 7(1), 177-184. https://doi.org/10.21744/irjmis.v7n1.835 
managers in companies with a high percentage of risk management apply the concept of conservatism to keep the company from uncertainty in the future. The manager will conduct an accrual policy in the form of earnings management to reduce earnings in the current period which will be distributed in the coming period to maintain the company's performance in the future to be stable. The action is taken by the manager will certainly have an impact on the decrease in earnings quality presented.

\section{Conclusion}

Based on the formulation of the problem, objectives, theoretical basis, hypotheses, the results of the analysis and discussion above presented, the following conclusions can be drawn.

a) Leverage has a negative and significant effect on earnings quality in banking sector companies listed on Indonesia Stock Exchange in 2016-2018. A high leverage ratio in a company will result in opportunistic actions of managers who carry out accrual policies in the form of earnings management to show good performance and get good ratings from creditors. Earnings management is carried out by managers will cause the company's earnings quality to decrease.

b) Free cash flow has a significant positive effect on earnings quality in banking sector companies listed on the IDX in 2016-2010. High free cash flow at companies indicates the company has cash for growth, debt payments, and dividend payments. Managers at companies with high free cash flow tend to avoid using accrual policies. This is conducted to maintain the credibility of financial statements and get a good rating from investors.

c) Managerial ownership has a significant negative effect on earnings quality in banking sector companies listed on the Stock Exchange in 2016-2018. A high percentage of managerial stock ownership will affect the higher accrual policies made by management. It reflects the poor quality of earnings generated on the company. The higher managerial shareholding will result in managers increasingly free to use the company's accrual policy to manage earnings which will have an impact on the resulting decrease in earnings quality.

d) Growth has a significant positive effect on earnings quality in banking sector companies listed on the Indonesia Stock Exchange in 2016-2018. The higher percentage of company growth will affect the lower accrual policy made by managers. It reflects the better earnings quality produced on the company. Companies with a good percentage of growth usually avoid earnings management practices to maintain the resulting earnings quality. This aim is to obtain a good judgment from investors who are sources of external funds used to grow.

e) Risk Management has a negative effect on earnings quality in banking sector companies listed on Indonesia Stock Exchange in 2016-2018. The high level of risk management indicates company managers take conservatism towards corporate profits. The managers are more concerned with the company's sustainability on conducting accrual policies in the form of earnings management in the current period to reduce the risks. It will be faced in the coming period. This action will certainly reduce the quality of generated profit.

\section{Conflict of interest statement}

The authors declared that they have no competing interests.

Statement of authorship

The authors have a responsibility for the conception and design of the study. The authors have approved the final article.

\section{Acknowledgments}

I am grateful to two anonymous reviewers for their valuable comments on the earlier version of this paper. 


\section{References}

Agustia, D. (2013). Pengaruh faktor good corporate governance, free cash flow, dan leverage terhadap manajemen laba. Jurnal Akuntansi dan Keuangan, 15(1), 27-42. https://doi.org/10.9744/jak.15.1.27-42

Collins, D. W., \& Kothari, S. P. (1989). An analysis of intertemporal and cross-sectional determinants of earnings response coefficients. Journal of accounting and economics, 11(2-3), 143-181. https://doi.org/10.1016/01654101(89)90004-9

Dewi, I. A. M. C., Sari, M. M. R., Budiasih, I., \& Suprasto, H. B. (2019). Free cash flow effect towards firm value. International Research Journal of Management, IT and Social Sciences, 6(3), 108-116. https://doi.org/10.21744/irjmis.v6n3.643

Dewi, I. G. A. A. O., \& Dewi, I. G. A. A. P. (2017). Corporate social responsibility, green banking, and going concern on banking company in Indonesia stock exchange. International Journal of Social Sciences and Humanities, 1(3), 118-134. https://doi.org/10.29332/ijssh.v1n3.65

Dira, K. P., \& Astika, I. B. P. (2014). Pengaruh Struktur Modal, Likuiditas, Pertumbuhan Laba, dan Ukuran Perusahaan pada Kualitas Laba. E-Jurnal Akuntansi, 64-78.

Dwiantika, N. (2018). Bank Bukopin tersandung kartu kredit. Diakses dari: https://keuangan.kontan.co.id/news/bankbukopin-tersandung-kartu-kredit.

Fahmi, I. (2013). Manajemen Strategis Teori dan Aplikasi. Bandung: Alfabeta.

Fidyati, N. (2003). Faktor-Faktor yang Mempengaruhi Kebijakan Hutang Perusahaan. Jurnal Ekonomi, Manajemen dan Akuntansi, 1(1), 17-34.

Gerald, I., White, S., Ashwinpaul, C., \& Fried, D. (2003). AIMR Annual Report Supplement to Accompany The Analysis and Use of Financial Statements. John Wiley \& Sons.

Goyal, A. (2010). Sustainable debt and deficits in emerging markets.

Hoyt, R. E., \& Liebenberg, A. P. (2011). The value of enterprise risk management. Journal of risk and insurance, 78(4), 795-822. https://doi.org/10.1111/j.1539-6975.2011.01413.x

Jensen, M. C., \& Meckling, W. H. (1976). Theory of the firm: Managerial behavior, agency costs and ownership structure. Journal of financial economics, 3(4), 305-360. https://doi.org/10.1016/0304-405X(76)90026-X

Kamaludin, K., Nikmah, N., \& Hijroini, H. (2016). Manajemen risiko, kualitas corporate governance, status keuangan perusahaan, dan perilaku opportunistik manajerial. fairness, 5(2), 88-109.

Kodriyah, K., \& Fitri, A. (2017). Pengaruh Free Cash Flow dan Leverage Terhadap Manajemen Laba Pada Perusahaan Manufaktur di BEI. JAK (Jurnal Akuntansi): Kajian Ilmiah Akuntansi, 4(1). http://dx.doi.org/10.30656/jak.v4i1.218

Marpaung, E. I. (2019). Pengaruh Leverage, Likuiditas, dan Ukuran Perusahaan Sebagai Variabel Moderasi Terhadap Kualitas Laba.

Nasih, M. (2014). Kualitas Laba dan Likuditas Saham; Studi di Bursa Efek Indonesia. Majalah Ekonomi Universitas Airlangga, 24(1).

Nozarpour, M., \& Norouzi, H. (2015). Investigating the Effect of Capital Structure and Growth Opportunities on Earnings Management. International Journal of Management, Accounting and Economics, 2 (6).

Nwaeze, E. T. (2010). The choice of operating cash flow in incentive compensation. The University Of Texas At San Antonio, College Of Business.

Peasnell, K. V., Pope, P. F., \& Young, S. (2005). Board monitoring and earnings management: do outside directors influence abnormal accruals?. Journal of Business Finance \& Accounting, 32(7-8), 1311-1346. https://doi.org/10.1111/j.0306-686X.2005.00630.x

Pitria, E. (2017). Pengaruh Kesempatan Bertumbuh, Leverage Dan Profitabilitas Terhadap Kualitas Laba (Studi Empiris pada Seluruh Perusahaan yang Terdaftar di BEI Selama Periode 2010-2014). Jurnal Akuntansi, 5(1).

Putra, Y. A. P., Purnamawati, I. G. A., \& Edy Sujana, S. E. (2017). Analisis Rasio Keuangan untuk Memprediksi Kondisi Financial Distress Perusahaan Manufaktur yang Terdaftar di Bursa Efek Indonesia. JIMAT (Jurnal Ilmiah Mahasiswa Akuntansi) Undiksha, 8(2). http://dx.doi.org/10.23887/jimat.v8i2.11230

Ramanuningsih, P. (2012). Pengaruh Roa, Leverage, Dan Growth Terhadap Kualitas Laba (Studi Empiris Perusahaan Basic Industry And Chemicals Yang Terdaftar Di Bursa Efek Indonesia 2007-2010).

Siallagan, H., \& Machfoedz, M. U. (2006). Mekanisme corporate governance, kualitas laba dan nilai perusahaan. Simposium Nasional Akuntansi IX. Padang, 23-26.

Tong, Y. H., \& Miao, B. (2011). Are dividends associated with the quality of earnings?. Accounting horizons, 25(1), 183-205. https://doi.org/10.2308/acch.2011.25.1.183

Yasa, G. S. W., Wirakusuma, M. G., \& Suaryana, I. G. N. A. (2020). Effect of leverage, free cash flow, corporate governance, growth and risk management on earnings quality. International Research Journal of Management, IT and Social Sciences, 7(1), 177-184. https://doi.org/10.21744/irjmis.v7n1.835 
Wahyuni, D. D. (2010). Analisis pengaruh mekanisme corporate governance terhadap manajemen laba (studi empiris perusahaan sektor perbankan yang terdaftar di BEI).

Wati, G. P., \& Putra, I. W. (2017). Pengaruh Ukuran Perusahaan, Leverage, dan Good Corporate Governance Pada Kualitas Laba. E-Jurnal Akuntansi, 137-167.

Wulansari, Y. (2013). Pengaruh Investment Opportunity Set, Likuiditas Dan Leverage Terhadap Kualitas Laba Pada Perusahaan Manufaktur Yang Terdaftar Di BEI. Jurnal Akuntansi, 1(2).

Zakaria, N. B., \& Daud, D. (2013). Does Big 4 affect the earnings response coefficient (ERC)? Evidence from Malaysia. Journal Of Modern Accounting and Auditing, 9(9). 